\title{
Influence of Service Recovery on Consumer Behavior in the Cities of Puebla and Queretaro, Mexico
}

\author{
Mariana Alfaro Cendejas
}

\begin{abstract}
This paper presents the results of research conducted in the cities of Puebla and Queretaro, Mexico, related to influence of service recovery of a brand on consumer behavior. The goal is to identify, from a customer perspective, negative implications of poor customer recovery and its effect on consumer behavior. Also, identify the main factors associated with affected customer loyalty after delivery mistakes and the way companies face the consequences.
\end{abstract}

Keywords - Service recovery, influence, and loyalty.

\section{Introduction}

\section{The Strategic Approach to Service Recovery}

In the last two decades, several authors have theoretically suggested the need to consider service recovery as a comprehensive set of management practices that allow companies to carry out recovery procedures in a proactive, relational and, ultimately, strategic way [1]. Therefore, long-term competitiveness requires service companies to incorporate a strategic approach to failure to allow learning, improve service quality, satisfaction and employee performance; always with the aim of creating and delivering value to current and future customers.

It is possible to observe service recovery as a comprehensive management system offered by the company as part of its value proposition, and not only with the operating procedures to recover from failures, but also as a valuable learning procedure. The strategic approach to service recovery should be the management priority in companies' services [2].

Mariana Alfaro Cendejas

UPAEP

México

\section{The Current Status of Service Recovery: Literature Review}

\section{Three Priority Lines of Research}

A first line of research focuses on types of recovery initiatives that are effective (Harris et al., 2006). For example, when service failure occurs, research suggests that companies must offer an apology [3], provide refunds [4], or deal with the service failure [5]. A second line of research analyzes the impact of perceived justice, emotions or recovery attributions on satisfaction, loyalty and word of mouth intentions in recovery situations [6]. A third trend in research studies, focuses on how service recovery efforts influence purchase intentions [7], trust and commitment [8]. Moderate to high service recovery efforts can increase user satisfaction and lead to satisfaction [9], trust and commitment.

To sum up, service recovery could be an opportunity to regain customer trust [10] increase engagement with customers [11], and build long-term relationships if the recovery is correct. Consumer experience undergoing service recovery is considered an important precedent for their loyalty in the long term (satisfaction, trust and commitment).

Consumer Behavior in the Era of Absolute Value and Service Recovery Paradox

\section{Service Recovery Paradox}

Even the most customer-focused organization, with the strongest quality program, is unlikely to be able to eliminate all service failures [12]. Service failure causes customer dissatisfaction with the service provider, and because of this, customers can leave without saying anything, expand the negative word of mouth, or express their complaints to the executive in charge [13]. Therefore, service 
recovery is a "moment of truth" for the company, essential for customer satisfaction and for strengthening its relations with them [14] y [15].

During the error, the customer experiences situations of dissatisfaction understood as a cognitive assessment or psychological state (negative assessment), in this way strategies provide a second chance to correct mistakes [16] Implementation of these initiatives proposes the existence of an organizational culture focused on creating customer value with a dynamic concept that requires the effort of learning, adaptation and continuous improvement of the organization [17].

There are three paradigms in the field of service recovery [18]:

1) Failure to meet expectations (Positive: it happens when the company performs better than expected, when the client receives an excellent recovery strategy resulting in a state of post-satisfaction). The recovery paradox emerges from this paradigm.

2) The script (considers awareness of family and frequent situations; it is stored in a part of memory as a coherent description of events expected to occur. In this way the process is kept in the client's memory as a sequence of actions waiting to take place in a specific order or as in a script. All this causes more attention and the evaluation of the mistake in recovery efforts in the customer's mind).

3) Commitment-trust (The mistake causes customer insecurity and affects trust in the company, which is why it must provide better recovery strategies giving the person in charge of dealing with the failure, personal confidence to acquire the commitment to act for the company and generate a state of trust recovery in the client).

\section{Conceptual Model of Service Recovery Paradox}

The notion of a "service recovery paradox" suggests that an effective recovery process is crucial to preserve or even improve customer satisfaction. In line with Boshoff and Leon [19], effective recovery should not be seen as the result of luck or natural skills of front-line employees, and it is suggested that to some extent it may be the result of competent improvisation, a practice that articulates several processes discussed in the existing recovery literature: orientation to action, training, rules and regulations, and the desire to deliver customer satisfaction.

\section{Study of Service Recovery in the Context of Puebla and Queretaro, Mexico}

The 2012 Urban Competitiveness Index compares 77 cities across 60 indicators grouped into 10 sub-indexes. It is a web platform that represents an economic and social observatory that allows comparisons between highly linked cities or urban environments. For the purposes of this study, we carried out a comparison between Queretaro and the Puebla-Tlaxcala binomial, to identify main similarities and differences between these two cities.

Although there are ranking differences in the Mexican Institute for Competitiveness (IMCO) platform between these two contrasting urban areas (Puebla-Tlaxcala in place 28 and Queretaro in place 4), there are more similarities than differences when comparing some particular items.

In the central proposal of this research, we will identify whether these indicators related to competitiveness of both cities influence service recovery of their institutions or on the contrary, this external ecosystem has nothing to do with that feature.

\section{Study Hypotheses}

According to revised literature and considering various factors on the subject of service recovery, we consider the following hypotheses for validation: 
Proc. of the Third Intl. Conf. on Advances in Management, Economics and Social Science - MES 2015.

Copyright (C) Institute of Research Engineers and Doctors, USA .All rights reserved.

ISBN: 978-1-63248-081-1 doi: 10.15224/ 978-1-63248-081-1-85

$\boldsymbol{H}_{1}:$ Businesses related with high investment products/services are more affected by an inefficient service recovery.

$\mathrm{H}_{2}:$ Service recovery is perceived as a component of justice and equity.

$\boldsymbol{H}_{3}$ : Service recovery paradox does not occur in Puebla and Queretaro.

$\boldsymbol{H}_{4}:$ Brand perception is directly affected by the response of the company in service recovery.

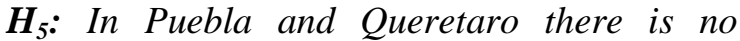
culture and institutional infrastructure to support consumers when a service failure takes place.

\section{Study and Results Obtained}

Validity and Reliability of the Instrument

Reliability is the accuracy or precision of a measuring instrument. There are different types of reliability: stability over time (measurable through a test-retest design); representation, which refers to the absence of variations in the instrument's ability to measure one same construct in different subpopulations; and finally, equivalency, which is applied to the latent variables, measured through multiple indicators, and which can be tested through a variety of methods, including the so-called Cronbach's alpha, two halves, and different ways to verify consistency between evaluators [20].

In addition, before implementation of the instrument used in this study, we conducted a pilot test with 10 people from the two analyzed populations ( 5 from each city), through which we adjusted some questions and even some of the multiple-choice answers. The Cronbach's alpha values obtained in the pilot test and later in the final study were 0.750 and 0.860 , acceptable and very good values respectively.

\section{Study Methodology}

An electronic survey was prepared and sent to people of a typical $\mathrm{C}$ socioeconomic status
(AMAI, http://nse.amai.org/data) onwards, in an age range of 20-65 years, living in the cities of Puebla and Queretaro. The online survey was available for a period of three calendar weeks, between March 24 and April 14, 2015, receiving a total of 176 responses.

\section{Participant General Information}

Gender-wise, considering the total of survey respondents: $54 \%$ were women and $46 \%$ men. In relation to total participation by city of origin: $56.3 \%$ correspond to the city of Queretaro and $43.2 \%$ to the city of Puebla. The main demographic differentiator between groups is age of people, while in Puebla average age is 44.39 years (with a 10.88 standard deviation) in Queretaro it is 33.30 years (with a 12.26 deviation), making this a difference of 11 years. As shown in Table 4, this effect is caused because most university students surveyed are in Queretaro, while most respondents in Puebla are employed (working age staff).

\section{Understanding the Term "Service Recovery"}

According to the results of the study, the concept "service recovery" refers respondents to one of the following meanings: 1 . The restoration of a service that no was longer offered $(24 \%)$; 2. Fixing a poorly delivered service $(22 \%) ; 3$. After-sales service offered by a company $(18 \%)$; 4. A guarantee offered by the company if a product fails $(13 \%) ; 5$. Attention to complaints $(9 \%)$; 6 . Refund of time or money invested $(6 \%)$; 7. Service failure compensation $(5 \%) ; 8$. Actions to change processes or personnel that does not deliver the promise of value in service delivery $(3 \%)$.

\section{Greater Impact Businesses}

According to surveyed population, businesses that provide bad service generally, in order of importance are: 1. Banking and financial services; 2. Government; 3. Cell phone providers; 4. Hospitals / Health Institutions and 5. Automotive agencies. In the comparative chart by city: 
Proc. of the Third Intl. Conf. on Advances in Management, Economics and Social Science - MES 2015.

Copyright (C) Institute of Research Engineers and Doctors, USA .All rights reserved.

ISBN: 978-1-63248-081-1 doi: 10.15224/ 978-1-63248-081-1-85

Table 1. Greater Impact Businesses in Service Recovery by City

\begin{tabular}{|c|c|}
\hline Puebla & Queretaro \\
\hline $\begin{array}{c}\text { 1. Banking and } \\
\text { financial } \\
\text { services } \\
(82.35 \%)\end{array}$ & $\begin{array}{c}\text { 1. Banking and } \\
\text { financial } \\
\text { services } \\
(78.13 \%)\end{array}$ \\
\hline $\begin{array}{c}\text { 2. Government } \\
(70.59 \%)\end{array}$ & $\begin{array}{l}\text { 2. Cell phone } \\
\text { providers } \\
(75 \%)\end{array}$ \\
\hline $\begin{array}{l}\text { 3. Hospitals / } \\
\text { Health } \\
\text { Institutions } \\
(70.59 \%)\end{array}$ & $\begin{array}{c}\text { 3. Government } \\
(62.50 \%)\end{array}$ \\
\hline $\begin{array}{l}\text { 4. Cell phone } \\
\text { providers } \\
(64.71 \%)\end{array}$ & $\begin{array}{c}\text { 4. Automotive } \\
\text { agencies } \\
(56.25 \%)\end{array}$ \\
\hline $\begin{array}{l}\text { 5. Automotive } \\
\text { agencies } \\
(54.90 \%)\end{array}$ & $\begin{array}{l}\text { 5. Hospitals / } \\
\text { Health } \\
\text { Institutions } \\
\text { and Auto } \\
\text { repair shops } \\
(53.13 \%)\end{array}$ \\
\hline
\end{tabular}

\section{Relation Network with Service Recovery}

Surveyed people relate the term "service recovery" more with: 1. Quality of service; 2. Ethics; 3. "Get what you pay for"; 4. Equity; 5. Justice; and 6. Brand awareness. In the analysis by city:

Table 2. Relation of the Service Recovery Term with other Concepts by City

\begin{tabular}{|c|c|}
\hline Puebla & Queretaro \\
\hline $\begin{array}{c}\text { Quality of service } \\
(58.82 \%)\end{array}$ & $\begin{array}{c}\text { Quality of service } \\
(54.84 \%)\end{array}$ \\
\hline Ethics $(21.57 \%)$ & Ethics $(16.13 \%)$ \\
\hline "Get what you pay & "Get what you pay \\
for" $(11.76 \%)$ & for" $(9.68 \%)$ \\
\hline Justice (3.92\%) & Equity (6.45\%) \\
\hline Equity (1.96\%) & $\begin{array}{c}\text { Brand awareness } \\
(6.45 \%)\end{array}$ \\
\hline $\begin{array}{c}\text { Brand awareness } \\
(1.96 \%)\end{array}$ & \begin{tabular}{c} 
Justice $(3.23 \%)$ \\
\hline Other $(0 \%)$
\end{tabular} \\
\hline
\end{tabular}

\section{Service Recovery Coverage and Viable Scope}

Almost $80 \%$ of respondents $(79.17 \%)$, say companies are not prepared to offer a service recovery after failure. In the comparative chart between the two cities, $83.34 \%$ in Puebla support this opinion, while the figure in Queretaro is $77.27 \%$.

\section{Expected Response versus Received Response}

Regarding action of a company that failed in the service, $30 \%$ of respondents say that the company "did nothing". And when an action took place, customers were more satisfied when: 1) The company acknowledged its mistake and apologized $(28.33 \%)$; 2) The company offered a larger incentive than the main purchase (24.17\%); 3) The company acknowledged its mistake $(11.67 \%)$; 4) The company issued a statement expressing its mistake (5.83\%).

\section{Effect on the Relationship with the Brand}

Considering the response of a company that failed in the service, perception of affected relationship with the brand was as follows: (1) Low (26.67\%); (2) Very low (25.00\%); (3) The same (24.17\%); (4) Superior (21.67\%) and (5) Highly superior (2.50\%).

\section{Puebla and Queretaro: Contrasts in Consumer Rights}

Globally, only $31.67 \%$ of respondents claim to have attended one of the official institutions to enforce their rights. Best-known institutions are: PROFECO (Federal Agency for Consumers Protection, 67.33\%), CONDUSEF (National Commission for the Protection of Users of Financial Services, 10\%), and lastly the National Consumer Institute (2\%). Some additional mentions include IFAI (Federal Institute for Access to Information and Data Protection), Apestan.com, National Employment Service, and customer service offices in companies.

As to obtained resolution, results were the following: 1. Positive, 2. Left in oblivion, due to no response; 3. Negative, 4. Other. Analyzing responses by city, the following data were obtained: 
Proc. of the Third Intl. Conf. on Advances in Management, Economics and Social Science - MES 2015.

Copyright (C) Institute of Research Engineers and Doctors, USA .All rights reserved.

ISBN: 978-1-63248-081-1 doi: 10.15224/ 978-1-63248-081-1-85

Table 3. Obtained Resolution by City

\begin{tabular}{|c|c|}
\hline Puebla & Queretaro \\
\hline Positive (35\%) & Positive (37.50\%) \\
\hline Negative (35\%) & $\begin{array}{c}\text { Left in oblivion, due to } \\
\text { no response (25\%) }\end{array}$ \\
\hline $\begin{array}{c}\text { Left in oblivion, due to } \\
\text { no response (30\%) }\end{array}$ & Negative (12.50\%) \\
\hline $\begin{array}{c}\text { Other (15\% was } \\
\text { positive but at the cost } \\
\text { of much investment in } \\
\text { time, resources, } \\
\text { emotional exhaustion) }\end{array}$ & $\begin{array}{c}\text { Other (25\%, they } \\
\text { required too many } \\
\text { documents) }\end{array}$ \\
\hline
\end{tabular}

\section{Hypotheses Results}

According to the results, we conclude the following, regarding established a priori hypotheses for the study:

$H_{1}$ : Businesses related with high investment products/services are more affected by an inefficient service recovery.

This is not accepted. Based on the answers given by participants to the question related to the greater impact businesses, the first places were occupied by banking and financial services, government (taxes), cell phone providers. Thereby pointing more at products / recurring operation services than to high-level investment ones.

$\mathrm{H}_{2}$ : Service recovery is perceived as a component of justice and equity.

This is partially accepted. Although the direct question does not provide answers related to justice and equity, but with quality of service. It is in response to what was done by the company after a failure where the demand for justice or equity is identified.

$H_{3}$ : Service recovery paradox does not occur in Puebla and Queretaro.

This is accepted. There are consequences after a service failure from the company in both cities and in very few cases there is evidence of a higher level of satisfaction than before the failure.

$\mathrm{H}_{4}:$ Brand perception is directly affected by the response of the company in service recovery.
This is accepted. Obtained results completely underpin this hypothesis, leaving a direct negative consequence on the brand-consumer relationship.

$H_{5}$ : In Puebla and Queretaro there is no culture and institutional infrastructure to support consumers when a service failure takes place.

This is rejected. While in Puebla the presence of such culture and institutional support is revealed, in Queretaro its absence is more evident.

\section{Conclusions of the Study and Future Research}

This study shows that there is no credibility in government institutions responsible for consumer rights. The government appears as the second most important element among institutions that do not offer service recovery as such. The differences between the two entities, that we could say are partly similar, Puebla and Queretaro, showed non-pronounced differences as to whether government institutions such as PROFECO, work for which they were created, being that the younger the people the less they believe less, and the older, they believe more.

Gender was a discriminatory variable in this analysis, while women think they gain less when the company wants to repair damage caused for not providing good service, unlike men, who say they feel discomfort when a service is not delivered as promised, but once time passes, they forget the issue of service recovery. It is recommended that future research carries out deeper random tests or by stratum, increasing sample size, extending age range, and using the instrument in various cities with a similar GDP or an equal or similar competitiveness to see how the study variables behave. It would be very appropriate to make some observations with representatives of the mentioned institutions (PROFECO) to know their view on the purpose of service recovery. 
Proc. of the Third Intl. Conf. on Advances in Management, Economics and Social Science - MES 2015. Copyright $(\odot$ Institute of Research Engineers and Doctors, USA .All rights reserved. ISBN: 978-1-63248-081-1 doi: 10.15224/ 978-1-63248-081-1-85

\section{References}

[1] Wang, K., Hsu, L. and Chih, W. (2014). Retaining customers after service failure recoveries: A contingency model, Managing Service Quality. Volume 24, Number 4, 2014.

[2] Johnston R. and Michel S. (2008) "Overcoming Recovery Myopia: Three Types of Service Recovery", International Journal of Operation \& Production Management, Vol 28 No 1, pp. 79-99.

[3] Webster C. y Sundaram (1998) DS. Service consumption criticality in failure recovery. J Bus Res 1998; 41:153 - 9 .

[4] Smith, A.K. and Bolton, R.N. (2002). The effects of customers' emotional responses to service failures on their recovery effort evaluations and satisfaction judgments. Journal of the Academy of Marketing Science, 30(1), 5-23.

[5] Harris, K. E., Grewal, D., Mohr, L. A., \& Bernhardt, K. L. (2006). Consumer responses to service recovery strategies: The moderating role of online versus offline environment. Journal of Business Research, 59(4), 425-432.

[6] Chebat, J. C., \& Slusarczyk, W. (2005). How emotions mediate the effects of perceived justice on loyalty in service recovery situations: an empirical study. Journal of Business Research, 58(5), 664-73.

[7] Maxham, J.G.I. (2001). "Service Recovery's Influence on Consumer Satisfaction, Word-of Mouth, and Purchase Intentions", Journal of Business Research, Vol 54 No October, pp. 11-24.

[8] Tax, S.S., Brown, S.W. and Chandrashekaran, M. (1998). "Customer evaluation of service complaint experiences: implications for relationship marketing", Journal of Marketing, Vol. 62, April, pp. 60-76.

[9] Ok, C., Back, K. J., \& Shanklin, C. W. (2005). Modeling roles of service recovery strategy: A relationship-focused view. Journal of Hospitality \& Tourism Research, 29(4), 484.

[10] Kelley SW, Hoffman KD, Davis MA (1993). A typology of retail failures and recoveries. J Retailing 1993; 69(4):429-52.

[11] Bejou, D. \& Palmer, A. 1998. "Service failure and loyalty: an exploratory empirical study of airline customers", Journal of Services Marketing, 12(1): 7-22.

[12] Del Rio-Lanza, A. B., Vazquez-Casielles, R., \& Diaz-Martin A.M. (2009). Satisfaction with service recovery: Perceived justice and emotional responses. Journal of Business Research, 62(8), 775-781.

[13] Kim, T., Kim, W. G., \& Kim, H. B. (2009). The effects of perceived justice on recovery satisfaction, trust, word-ofmouth, and revisit intention in upscale hotels. Tourism Management, 30, 51-62.

[14] Blodgett, J. G., Hill, D. J., \& Tax, S. S. (1997). The effects of distributive, procedural, and interactional justice on postcomplaint behavior. Journal of Retailing, 73(2), 185-210.

[15] Smith, A.K. and Bolton, R.N. (2002). The effects of customers' emotional responses to service failures on their recovery effort evaluations and satisfaction judgments. Journal of the Academy of Marketing Science, 30(1), 5-23.
[16] Vázquez, R., Diaz, A., Suárez, Río (2007).Quality of past performance: Impact on consumers' responses to service failure. Marketing Letter. Volume 18, Issue 4, pp 249-264

[17] Zu, Z., Sivakumar, K. y Parasuraman, A. (2004). A mathematical model of service failure and recovery strategies. D. Sciences, vol. 35, $\mathrm{n}^{\circ} 3$ (Summer), 493-525.

[18] Matos, C., \& Vargas, C. (2007). Service Recovery Paradox: A Meta-Analysis. Journal of Service Research 2007; 10; 60. DOI: $10.1177 / 1094670507303012$

[19] Boshoff, C. and Leon, J. (1998), "Empowerment, attribution and apologizing as dimensions of service recovery: an experimental study", International Journal of Service Industry Management, Vol. 9 No. 1, pp. 24-47.

[20] Mason, R., Lind, D. (1999). Statistics for Management and Economics. 8th. Edition. Mexico. Editorial Alfa-Omega.

\section{About Author:}

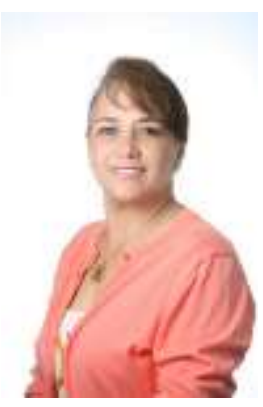

"Long-term

competitiveness requires

service companies to

incorporate a strategic

approach to failure to

allow learning, improve

service quality,

satisfaction and employee

performance; always with

the aim of creating and

delivering value to current

and future customers". 